\title{
ANALISIS MODEL PEMBELAJARAN EKSPOSITORI TERHADAP PEMAHAMAN KONSEP FISIKA DAN HASIL BELAJAR SISWA
}

\author{
Dina Hanifah Mansur ${ }^{1)}$, Nana ${ }^{2)}$ \\ Pendidikan Fisika FKIP Universitas Siliwangi \\ Tasikmalaya Jawa Barat Indonesia 46115 \\ E-mail: dinahanifahmansur@gmail.com \\ Corresponding author: nana@unsil.ac.id
}

\begin{abstract}
This study aims to describe the expository learning model. This writing was motivated by the lack of students' ability to understand concepts related to the material in physics learning so that the learning applied was not optimal. For this reason, there is a need for innovation in learning, namely by applying an expository learning model. The expository learning model is a process of understanding the concept of the material through the stage of delivering material in the form of direct explanations by the teacher to students, question and answer, question and answer exercises and assignments during the learning process. The method used in this research is literature study by reviewing some of the literature for analysis and making conclusions. The results showed that the expository learning model could improve student learning outcomes in physics learning on student learning outcomes.
\end{abstract}

Keywords: Expository Learning Model, Understanding Physics Concepts, Learning Outcomes.

\begin{abstract}
Abstrak: Penelitian ini bertujuan untuk mendeskripsikan model pembelajaran ekspositori. Penulisan ini dilatarbelakangi oleh masih kurangnya kemampuan siswa dalam memahami konsep terkait materi pada pembelajaran fisika sehingga pembelajaran yang diterapkan belum maksimal. Untuk itu perlu adanya inovasi dalam pembelajaran yaitu dengan menerapkan model pembelajaran ekspositori. Model pembelajaran ekspositori sebagai proses memahami konsep materi melalui tahap penyampaian materi berupa penjelasan langsung oleh guru kepada siswa, tanya jawab, latihan soal dan pemberian tugas selama proses pembelajaran. Metode yang digunakan dalam penelitian ini adalah studi kepustakaan yaitu dengan mengkaji beberapa literatur untuk dianalisis dan dibuat kesimpulan. Hasil penelitian menunjukkan bahwa model pembelajaran ekspositori dapat meningkatkan pemahaman konsep siswa pada pembelajaran Fisika terhadap hasil belajar siswa.
\end{abstract}

Kata kunci: Model Pembelajaran Ekspositori, Pemahaman Konsep Fisika, Hasil Belajar.

\section{PENDAHULUAN}

Fisika sebagai salah satu cabang dari IPA yang mempelajari gejala-gejala alam dan peristiwa alam baik yang dapat dilihat maupun yang bersifat abstrak. Berdasarkan hasil observasi proses pembelajaran fisika masih dengan menggunakan metode ceramah sehingga peserta didik sulit menerima atau menangkap materi pelajaran yang disampaikan. Sementara itu kebanyakan guru dalam mengajar masih tidak melakukan pembelajaran bermakna, model yang digunakan kurang bervariasi, sehingga cara belajar peserta didik cenderung menghafal. Peserta didik juga sering beranggapan bahwa pelajaran fisika sangat sulit dan 
membosankan karena banyak rumus-rumus yang harus dihafal dan dipahami, sehingga kenyataan yang dapat dilihat bahwa dalam hasil belajar fisika yang dicapai peserta didik masih rendah. (Hasbiyalloh, A. S., Harjono, A., \& Verawati, N. N. S. P., 2017).

Menurut Widodo (dalam Riwanto, D., Azis, A., \& Arafah, K., 2019), langkah awal yang paling tepat untuk mempelajari fisika adalah memahami konsepnya terlebih dahulu. Konsep-konsep pembelajaran tersusun secara sistematis. Sehingga diperlukan penguasaan konsep dalam setiap materi pelajaran sebelum melanjutkan ke materi selanjutnya. Konsep yang lebih awal diajarkan akan menjadi dasar bagai pengembangan konsep-konsep selanjutnya.

Untuk mencapai hasil belajar fisika yang memuaskan, peranan guru sangat diperlukan dalam penerapan model dan strategi belajar yang tepat sehingga tercapai tujuan pembelajaran. Menurut Suyatno (dalam Supriyatun, dalam Ariani, T., 2017) untuk mencapai tujuan pembelajaran adalah menggunakan strategi pembelajaran yang seirama dengan kondisi siswa, tujuan, dan kondisi pembelajaran yang akan dilangsungkan. Strategi pembelajaran yang dimaksud adalah pembelajaran yang berpusat kepada guru (teacher oriented), guru sebagai fasilitator dalam pembelajaran dan mengajak siswa untuk berpikir lebih kritis pada kegiatan diskusi yang dilakukan dalam pembelajaran. Strategi pembelajaran tersebut adalah Strategi Pembelajaran Ekspositori. Sehingga dalam hal ini salah satu model pembelajaran yang coba dianalisis adalah model pembelajaran ekspositori terhadap hasil belajar fisika.

\section{METODE PENELITIAN}

Metode yang digunakan dalam penulisan ini berupa studi kepustakan. Data dikumpulkan untuk dianalisis kemudian disajikan dalam hasil dan pembahasan agar dapat dibuat kesimpulan.

\section{HASIL DAN PEMBAHASAN}

\subsection{Model Pembelajaran Expositori}

Model pembelajaran ekspositori adalah model pembelajaran ekspositori adalah model pembelajaran

yang digunakan untuk menyampaikan keterangan terlebih dahulu berupa definisi, prinsip dan konsep materi pelajaran. Model ini merupakan model pembelajaran konvensional yang selalu digabungkan dengan metode lain seperti metoda demonstrasi, tanya jawab dan penugasan (Suniti, NM., 2015).

Dalam penelitian lain dituliskan bahwa model pembelajaran ekspositori adalah model pembelajaran yang menekankan pada proses penyampaian materi secara verbal dari seorang guru kepada sekelompok peserta didik dengan maksud agar peserta didik dapat menguasai materi pembelajaran secara optimal (Hasbiyalloh, A. S., Harjono, A., \& Verawati, N. N. S. P., 2017).

Menurut Romiszowski tahun 1990 dalam Buku Inovasi Pembelajaran (Nana, 2019) langkah-langkah pembelajaran ekspositori adalah sebagai berikut: 
1. Penyampaian materi

2. Apersepsi terhadap materi yang diajarkan

3. Penjelasan fakta, konsep, prinsip dan lain-lain

4. Tanya jawab, demonstrasi, diskusi dan lain-lain

5. Latihan soal-soal

6. Rangkuman

7. Tindak lanjut, seperti: PR dan tugas lain Menurut Sanjaya (dalam Suyitno, dalam Hasbiyalloh, A. S., Harjono, A., \& Verawati, N. N. S. P., 2017) langkah-langkah dalam model expository learning adalah:

1) Persiapan (Preparation), merupakan langkah yang penting, karena keberhasilan pelaksanaan sangat tergantung pada persiapan. Beberapa hal yang dilakukan dalam langkah persiapan, diantaranya adalah: (a) berikan sugesti positif dan hindari sugesti negatif, (b) mulailah dengan mengemukakan tujuan yang harus dicapai, (c) bukalah file dalam otak siswa, materi pelajaran bisa ditangkap dan disimpan dalam memori manakala sudah tersedia file yang sesuai.

2) Penyajian (Presentation), yaitu langkah penyampaian materi pelajaran sesuai dengan persiapan yang telah dilakukan. Guru harus memikirkan dalam penyajian ini bagaimana agar materi pelajaran dapat dengan mudah ditangkap dan dipahami oleh siswa. Karena itu, ada beberapa hal yang harus diperhatikan dalam pelaksanaan langkah ini, yaitu: (a) penggunaan bahasa, bahasa yang digunakan sebaiknya komunikatif, dan mudah dipahami, serta guru harus memperhatikan perkembangan siswa, (b) Intonasi suara, pengaturan suara harus sesuai dengan pesan yang disampaikan, (c) menjaga kontak mata dengan siswa, kontak mata sangat penting untuk membuat siswa memperhatikan pelajaran.

3) Menghubungkan (Corellation), langkah menghubungkan materi pelajaran dengan pengalaman siswa atau dengan hal-hal lain yang memungkinkan siswa dapat menangkap keterkaitannya dalam struktur pengetahuan yang telah dimilikinya.

4) Menyimpulkan (Generalization), tahapan untuk memahami inti (core) dari materi pelajaran yang telah disajikan. Langkah menyimpulkan merupakan langkah yang sangat penting dalam expository learning, sebab melalui langkah menyimpulkan siswa akan dapat mengambil inti sari dari proses penyajian.

5) Penerapan (Aplication), langkah unjuk kemampuan siswa setelah mereka menyimak penjelasan guru. Langkah ini merupakan langkah yang sangat penting dalam proses expository learning, sebab melalui langkah ini guru akan dapat mengumpulkan informasi tentang penguasaan dan pemahaman materi pelajaran oleh siswa. Teknik yang biasa dilakukan pada langkah ini di antaranya: (1) dengan membuat tugas yang relevan dengan materi yang telah disajikan, (2) dengan memberikan tes yang sesuai dengan materi pelajaran yang telah disajikan. 
Dalam penelitian lain dijelaskan bahwa langkah-langkah pembelajaran ekspositori adalah sebagai berikut:

1) Pada tahap pendahuluan guru menyampaikan pokok-pokok materi yang akan dibahas dan tujuan pembelajaran yang ingin dicapai;

2) Pada tahap inti guru menyampaikan materi dengan ceramah, tanya jawab, demonstrasi;

3) Pada tahap penutup guru memberikan evaluasi (Suniti, N. M., 2015).

Berdasarkan uraian di atas dapat disimpulkan bahwa model pembelajaran ekspositori merupakan model pembelajaran yang menekankan kepada proses penyampaian materi berupa penjelasan langsung dari guru kepada siswa.

\subsection{Kelebihan dan Kelemahan Model Pembelajaran Ekspositori}

Menurut Sanjaya dalam (Hasbiyalloh, A. S., Harjono, A., \& Verawati, N. N. S. P., 2017) Keunggulan model pembelajaran ini adalah (a) dengan model pembelajaran ekspositori guru bisa mengontrol urutan dan keluasan materi pembelajaran, dengan demikian guru dapat mengetahui sampai sejauh mana peserta didik menguasai bahan pelajaran yang disampaikan, (b) model pembelajaran ekspositori dianggap sangat efektif apabila meteri pembelajaran yang harus dikuasai peserta didik cukup luas, sementara itu waktu yang dimiliki untuk belajar terbatas, (c) melalui model pembelajaran ekspositori selain peserta didik dapat mendengar melalui penuturan (kuliah) tentang suatu materi pelajaran, juga sekaligus peserta didik bisa melihat atau mengobservasi (melalui pelaksanaan demonstrasi), dan (d) model pembelajaran ini bisa digunakan untuk jumlah peserta didik dan ukuran kelas yang besar.

Disamping memiliki kelebihan, model pembelajaran ekspositori juga memiliki kelemahan, di antaranya: a) Model pembelajaran ini hanya mungkin dapat dilakukan terhadap siswa yang memiliki kemampuan mendengar dan menyimak secara baik. Untuk siswa yang tidak memiliki kemampuan seperti itu perlu digunakan model pembelajaran lain. b) Expository learning ini tidak mungkin dapat melayani perbedaan setiap individu baik perbedaan kemampuan, perbedaan pengetahuan, minat, dan bakat, serta perbedaan gaya belajar. c) Karena expository learning lebih banyak diberikan melalui ceramah, maka akan sulit mengembangkan kemampuan siswa dalam hal kemampuan sosialisasi, hubungan interpersonal, serta kemampuan berpikir kritis. d) Keberhasilan expository learning sangat tergantung kepada apa yang dimiliki guru, seperti persiapan, pengetahuan, rasa percaya diri, semangat, antusiasme, motivasi, dan berbagai kemampuan seperti kemampuan bertutur (berkomunikasi), dan kemampuan mengelola kelas, tanpa itu sudah dapat dipastikan proses pembelajaran tidak mungkin berhasil.

\subsection{Pemahaman Konsep}


Menurut Arens (dalam Ernasari, 2019), konsep adalah alat yang dipakai untuk mengorganisasikan pengetahuan serta pengalaman ke berbagai kategori. Konsep dapat terbentuk dari pengalaman secara langsung dengan suatu objek/peristiwa dalam kehidupan sehari-hari.

Pemahaman konsep adalah proses perbuatan untuk mengerti benar tentang suatu rancangan atau suatu ide abstrak yang memungkinkan seseorang untuk menggolongkan suatu objek atau kejadian, dan pemahaman konsep diperoleh melalui proses belajar. Pemahaman merupakan hasil belajar mengajar yang mempunyai indikator dan setiap individu dapat menjelaskan atau mendefenisikan suatu bagian informasi dengan kata-kata sendiri (Elisa, E., Mardiyah, A., \& Ariaji, R., 2017).

Penguasaan konsep dimaknai sebagai kemampuan yang dipunyai seseorang untuk menjelaskan kembali apa yang sudah disampaikan atau atau dikaji/ dieksplorasi (Ernasari, 2019).

Permendiknas (dalam Ernasari, 2019) mengungkapkan bahwa, pemahaman konsep merupakan salah satu kecakapan atau kemahiran Fisika yang diharapkan dapat tercapai dalam belajar Fisika yaitu dengan menunjukkan pemahaman konsep Fisika yang dipelajarinya, menjelaskan keterkaitan antar konsep dan mengaplikasikan konsep secara luwes, akurat, efisien, dan tepat dalam pemecahan masalah.

Berdasarkan Permendiknas tahun 2016 (dalam Ernasari, 2019) indikator pemahaman konsep di antaranya adalah: Menyatakan ulang suatu konsep; Mengklarifikasikan objek-objek menurut sifat-sifat tertentu; Memberi contoh dan non-contoh dari konsep; Menyajikan konsep dalam berbagai bentuk representasi; Mengembangkan syarat perlu dan syarat cukup sautu konsep; Menggunakan, memanfaatkan, dan memilih prosedur atau operasi tertentu dan Mengaplikasikan konsep atau pemecahan masalah.

\subsection{Hasil Belajar}

Hasil belajar menurut Susanto (dalam Ardani, A., Rahmawati, D., \& Awaludin, A. A. R., 2020) adalah tingkat keberhasilan siswa dalam mempelajari materi pelajaran disekolah yang dinyatakan dalam skor dan diperoleh dari hasil tes mengenal sejumlah materi pelajaran tertentu.

Menurut Rusmono hasil belajar dapat diartikan sebagai perubahan perilaku individu yang meliputi ranah kognitif, afektif, dan psikomotorik. Perubahan perilaku tersebut diperoleh setelah selesai menyelesaikan program pembelajarannya melalui interaksi dengan berbagai sumber belajar dan lingkungan belajar (Ardani, A., Rahmawati, D., \& Awaludin, A. A. R., 2020).

Hasil belajar kognitif diartikan gambaran kualitas kemampuan siswa pada pokok bahasan yang diperolehnya (Shi, et. al dalam Yuliani, N., 2020). Selain itu menurut Kennedy (dalam Yuliani, N., 2020) hasil belajar kognitif juga merupakan kemampuan siswa terhadap pengetahuan atau teori dalam proses kegitan belajar untuk mengembangkan kemampuan dan keterampilan siswa melalui konsep, aturan, serta fakta-fakta yang telah dipelajari oleh siswa. 


\subsection{Analisis Model Pembelajaran Ekspositori Terhadap Pemahaman Konsep Fisika dan Hasil Belajar}

\section{Siswa}

Pada proses pembelajaran fisika, banyak siswa yang kurang memahami suatu konsep dalam materi sehingga berpengaruh terhadap hasil belajar siswa. Melalui model pembelajaran ekspositori, proses pembelajaran siswa menjadi lebih bermakna dan dapat memahami konsep dengan baik. Pada proses pembelajarannya guru akan menyampaikan materi secara langsung menjelaskan kepada siswa dimulai dari konsep-konsep dasar sehingga siswa dapat memahaminya dengan baik sehingga akan ada pengaruh terhadap hasil belajar siswa.

Pada penelitian Ariani, T. (2017) "Penerapan Strategi Pembelajaran Ekspositori untuk Meningkatkan Hasil Belajar Fisika" menunjukkan bahwa ada peningkatan hasil belajar dengan menggunakan strategi pembelajaran ekspsositori siswa kelas X SMA Negeri 8 Lubuklinggau berdasarkan hasil analisis uji-t pada taraf signifikan $\alpha=0,05$, didapat thitung $=5,86$ dan $\mathrm{t}$ tabel $=1,71$ karena $\mathrm{t}$ hitung $>\mathrm{t}$ tabel.

\section{PENUTUP}

Berdasarkan hasil dan pembahasan yang telah dijabarkan dapat ditarik kesimpulan bahwa dengan model pembelajaran ekspositori dapat siswa dalam memahami suatu konsep materi pada pembelajaran Fisika.

\section{UCAPAN TERIMA KASIH}

Terima kasih kepada semua pihak yang telah membantu demi kesempurnaan penulisan ini menjadi lebih baik, khususnya kepada bapak Dr. Nana, M. Pd., selaku Dosen Pembimbing.

\section{DAFTAR PUSTAKA}

Ardani, A., Rahmawati, D., \& Awaludin, A. A. R. (2020). Pengaruh Model Pembelajaran Meaningful Instructional Design Berbantuan Media Ular Tangga Terhadap Hasil Belajar Matematika. Apotema: Jurnal Program Studi Pendidikan Matematika, 6(2), 103-111.

Ariani, T. (2017). Penerapan Strategi Pembelajaran Ekspositori untuk Meningkatkan Hasil Belajar Fisika. Jurnal Inovasi dan Pembelajaran Fisika, 4(1), 18-26

Elisa, E., Mardiyah, A., \& Ariaji, R. (2017). Peningkatan Pemahaman Konsep Fisika dan Aktivitas Mahasiswa melalui PhET Simulation. PeTeKa, 1(1), 15-20. 
Ernasari. (2019). Pengembangan Perangkat Pembelajaran Fisika Berbasis Kearifan Lokal Rabi Ro’o untuk Mengukur Pemahaman Konsep dan Nasionalisme Pada Peserta Didik Kelas X SMA/MA. (Tesis. Yogyakarta: Program Pascasarjana, Universitas Negeri Yogyakarta)

Hasbiyalloh, A. S., Harjono, A., \& Verawati, N. N. S. P. (2017). Pengaruh model pembelajaran ekspositori berbantuan scaffolding dan advance organizer terhadap hasil belajar fisika peserta didik kelas X. Jurnal Pendidikan Fisika dan Teknologi, 3(2), 173-180.

Heryadi, D., \& Sundari, R. S. (2020). Expository Learning Model. International Journal of Education and Research, 8(1), 207-216.

Nana. (2019). Inovasi Pembelajaran. Klaten: Lakeisha.

Riwanto, D., Azis, A., \& Arafah, K. (2019). Analisis pemahaman konsep peserta didik dalam menyelesaikan soal-soal fisika kelas x mia sma negeri 3 soppeng. Jurnal Sains dan Pendidikan Fisika, 15(2).

Suniti, N. M. (2015). Model Ekspositori Dapat Meningkatkan Prestasi Belajar Matematika Dalam Kompetensi Dasar" Memfaktorkan Bentuk Aljabar". Jurnal Santiaji Pendidikan (JSP), 5(2), 96-102.

Yuliani, N. (2020). Pengaruh Model Pembelajaran Meaningfull Instructional Design Terhadap Hasil Belajar Kognitif Siswa pada Mata Pelajaran Matematika. Al-Tarbiyah: Jurnal Pendidikan (The Educational Journal), 30(1), 37-47. 